\title{
A Study on Career Maturity of XI Standard Students
}

\author{
B. Sivakumar ${ }^{1 *}$, N. Sridhar ${ }^{1}$
}

\section{ABSTRACT}

The nature of career maturity is influenced by number of factors. The factors like the individuals family environment, mental ability, attitude, personality, economic, political and industrial polices etc... Considering the above facts, it will be relevant to study the career maturity and career competency of students. Career Maturity Inventory (CMI) Attitude Scale \& Competency Test) originally prepared by John O, Crites, Indian Adaptation by Mrs. Nirmala Gupta (1989). The reliability of the scale was found to be 0.82 . Normative survey method was used for the present study. This method was used to assess the relationship between the XI standard Students career maturity and their career competency. A random sample of 200 XI Students studying in eight Higher Secondary Schools located in Erode district of Tamil Nadu was selected for the study. The investigator was used by t and F test.

\section{Keywords: Carrer, Maturity, Students}

Twenty first century is witnessing radical changes in every field due to tremendous scientific and technology advancement. The education is not exception for it. Education has become a powerful tool of social change, especially in a society in which the majorities are poor. The World Bank Study Opined, "Education is to corner stone of economic growth and social development and principal means of improving the welfare of individuals. (The Hindu 24.3.1998) an Educational helps a student the thinking decisively and inculcating sense of responsibility towards the world around him. The growth and status of education indicates the level of development of a society. In modern societies, career choices have become wide and certain jobs require specialized knowledge and skills that are based on the level of education.

\section{Statement of the Problem}

The nature of career maturity is influenced by number of factors. The factors like the individuals family environment, mental ability, attitude, personality, economic, political and industrial polices etc... However, a person's career maturity is mainly determined by his family environment, mental ability and attitude. The family as a biological unit begins to influence the career development of the individuals before his birth, from the moment of his conception.

\footnotetext{
${ }^{1}$ Asst. Prof. in Education, Vellalar College of Education for women, Maruthi Nagar, Thindal, Erode, Tamil Nadu state, India

*Responding Author

(C) 2016 I B Sivakumar, N Sridhar; licensee IJIP. This is an Open Access Research distributed under the terms of the Creative Commons Attribution License (http://creativecommons.org/licenses/by/2.0), which permits unrestricted use, distribution, and reproduction in any Medium, provided the original work is properly cited.
} 
Physical factors such as the geographical location of the family may, at times have a significant effect on the career maturity of the individual. Ability is another important factor in choosing a career. Students with higher intellectual ability tend to seek and prepare for jobs which require higher kind of intelligence, while the intelligence, while the ones with career mental ability tend to seek and prepare for jobs which require higher kind go in for semi-skilled jobs and continue in position of almost no importance. Considering the above facts, it will be relevant to study the career maturity and career competency of students. Therefore, the investigator rightly chose the topic “A study on Career Maturity of XI Standard Students”.

\section{NEED AND IMPORTANCE OF THE STUDY}

The world today is a highly complex and rapidly changing one. There are changing requirements in industrial jobs, altered market conditions for professional manpower, the development of paraprofessional occupations and many other labour market trends which make career selection more difficult than ever. Skilled manpower is an essential pre-requisite for quality and efficient production, adaptation and use of new technology. Most of our students stand like directionless ships. Majority of them lack no clear objectives $\mathrm{r}$ career targets. They amble though university courses of learning without acquiring much knowledge of preparing themselves for an uncertain future. Only few students pursue their education or choose their career with clear idea as to what they would eventually like to become.

After completing the Higher Secondary Course there is situation most of the students especially in rural areas undecided about their future career. This study will be helpful to be students to select their future careers according to their environment, needs interests, and their ability.

\section{REVIEW OF RELATED LITERATURE}

Matur Gul (2001) conducted a study on career maturity among adolescents. The result showed that both boys and girls had equal level of career competency. A significant correlation was found between each dimension of career competency. Louis A. Busacca and Brian J. Taber (2002) the career maturity inventory - revised. A preliminary psychometric investigation. The primary purpose of this study was to obtain estimates of internal consistency reliability, as well as to examine evidence of the construct and criterion validity of the Career Maturity InventoryRevised (CMI-R) attitudes appears ready to make wise and congruent occupational choices. Mark L. Savickas (2002) study revealed the relation of career maturity to personality type and social adjustment. The results indicated that more mature attitudes toward career planning and exploration related to an adjustment style characterized by extroversion in interpersonal relationships and by a positive orientation to social norms. Robert T.Career and Madonna G.Constantne (2002) studied the career maturity, Life Role Salience, and Racial/Ethnic identity in black and Asian American college students. The findings are discussed in terms of their implications for the career development of black and Asian Americans. Wendy Patton (2002) career maturity and well-being as determinants of occupational status of recent school leavers: A brief report of an Australian study. Findings support the assertion that career maturity is a 
predictor of a successful post school transition. Careed (2003) predicting two components of career maturity in school based adolescents. Results demonstrated the importance of examining tow aspects of career maturity (attitude and knowledge), and were discussed in the context of super's (1957, 1990) theory of career development. Robert Hogan and Brent W. Roberts (2004) studied the socio-analytic model of maturity. The authors briefly review some data bearing on these observations. Shantha $\mathbf{T}$ (2008) conducted a study on career maturity of higher secondary students and found that the higher secondary student's career maturity and career competency is low. Further, there is a significant relationship exists between the higher secondary students career maturity and career competency. The investigator was 40 studies collected on abroad and India.

\section{OBJECTIVES OF THE STUDY}

The present has the following objectives.

- To find out the XI standard school students level of career maturity and career competency.

- To find out if there is any significant difference between the following demographic variables of XI standard school students of career maturity.

o Boys and Girls

o Rural and Urban

o Aided and Government

o Nuclear and Joint Family

- To find out if there is any significant difference among the following demographic variables of XI standard school students of career maturity.

o Hindu, Christian and Muslim

o OC, BC, MBC and SC/ST

- To find out if there is any significant difference between the following demographic variables of XI standard school students of career competency.

o Boys and Girls

o Rural and Urban

o Aided and Government

o Nuclear and Joint Family

- To find out if there is any significant difference among the following demographic variables of XI standard school students of career competency.

o Hindu, Christian and Muslim

o OC, BC, MBC and SC/ST

- To find out if there is any significant relationship exists between the XI standard school student's level of career maturity and career competency.

\section{Hypotheses of the Study}

- The XI standard student's level of career maturity and career competency is low.

- There is no significant difference between the following demographic variable of XI standard school students of career maturity

o Boys and Girls

o Rural and Urban 


\section{A Study on Career Maturity of XI Standard Students}

o Aided and Government

o Nuclear and Joint Family

- There is no significant difference among the demographic variables of XI standard school students of career maturity.

o Hindu, Christian and Muslim

o OC, BC, MBC and SC/ST

- There is no significant difference between the following demographic variable of XI standard school students of career competency

o Boys and Girls

o Rural and Urban

o Aided and Government

o Nuclear and Joint Family

- There is no significant difference among the demographic variables of XI standard school students of career competency.

o Hindu, Christian and Muslim

o OC, BC, MBC and SC/ST

- There is no significant relationship between the XI standard school student's level of career maturity and career competency.

\section{Tool Used}

Career Maturity Inventory (CMI) Attitude Scale \& Competency Test) originally prepared by John O, crites, Indian Adaptation by or Mrs. Nirmala Gupta (1989). The reliability of the scale was found to be $\mathbf{0 . 8 2}$ by test-retest reliability method. The scale has a high content and constructs validity as expressed by experts in guidance. The items of the attitude scale show development scores over Class XII which also established the validity of the scale in the Indian sample.

\section{METHOD}

Normative survey method was used for the present study. This method was used to assess the relationship between the XI standard Students career maturity and their career competency. A random sample of 200 XI Students studying in eight Higher Secondary Schools located in Erode district of Tamil Nadu was selected for the study.

\section{Method of Data Analysis}

Data analysis refers to a process which entails an effort to formally identify themes and to construct hypotheses as they are suggested by data and an attempt to demonstrate support for those hypotheses.

Analysis of the data in the present study is done in such a way to focus on comparison career maturity of Higher Secondary Students in relation to their family environment. The impact of gender, locality, type of management, religion, community on career maturity and career competency of XI standard Students has been analyzed in this study. The data are descriptively analyzed by computing Mean and Standard Deviation. The difference in the mean value of 
career maturity and career competency scores of the various sub groups are tested for their significances.

The test of significance ( $\mathrm{t}$ test) is used in order to find the significance of the difference between any two means of the career maturity and career competency scores. In order to find whether the differences in career maturity and career competency scores for more than two groups are significant or not, the ' $F$ ' tests is applied. The Pearson's correlation method has been employed in order to study the relationship of one variable to another.

ANALYSIS AND INTREPRETATION OF DATA/HYPOTHESIS

Table 1, Mean and SD Scores of Career Maturity of XI Standard Students

\begin{tabular}{|c|c|c|c|c|c|}
\hline Sl. No & Demo graphic Variables & Sub-samples & $\mathbf{N}$ & Mean & SD \\
\hline \multirow{2}{*}{1} & \multirow{2}{*}{ Gender } & Boys & 98 & 23.38 & 5.11 \\
\hline & & Girls & 102 & 24.80 & 5.80 \\
\hline \multirow{2}{*}{2} & \multirow{2}{*}{ Location of the School } & Rural & 86 & 24.11 & 5.29 \\
\hline & & Urban & 114 & 24.10 & 5.69 \\
\hline \multirow{2}{*}{3} & \multirow{2}{*}{$\begin{array}{l}\text { Type of School } \\
\text { Management }\end{array}$} & Private & 107 & 24.44 & 5.42 \\
\hline & & Government & 93 & 23.72 & 5.60 \\
\hline \multirow{2}{*}{4} & \multirow{2}{*}{ Type of the Family } & Joint family & 60 & 24.05 & 6.94 \\
\hline & & Nuclear family & 140 & 24.13 & 4.79 \\
\hline \multirow{3}{*}{5} & \multirow{3}{*}{ Religion } & Hindu & 187 & 24.19 & 5.37 \\
\hline & & Christian & 5 & 20.80 & 10.63 \\
\hline & & Muslim & 8 & 24.25 & 4.77 \\
\hline \multirow{4}{*}{6} & \multirow{4}{*}{ Community } & $\mathrm{OC}$ & 18 & 23.66 & 5.92 \\
\hline & & $\mathrm{BC}$ & 86 & 23.88 & 5.22 \\
\hline & & MBC & 49 & 24.59 & 5.10 \\
\hline & & SC/ST & 47 & 24.19 & 6.34 \\
\hline \multicolumn{3}{|c|}{ Total Sample } & 200 & 24.11 & 5.51 \\
\hline
\end{tabular}

It could be observed from the table 1 the mean scores of the total sample is found to be 24.11. It denotes that the XI standard student's level of career maturity is below average. Hence the null hypothesis 1 is accepted. Further the means scores indicate that irrespective of the XI standard student gender, location of the school, type of school management, type of family, religion and Community, the level f career maturity is below average. 
Table 2, Mean and SD Scores of Career Competency of XI Standard Students

\begin{tabular}{|c|c|c|c|c|c|}
\hline Sl. No & Demographic Variables & Sub-samples & $\mathbf{N}$ & Mean & SD \\
\hline \multirow{2}{*}{1} & \multirow{2}{*}{ Gender } & Boys & 98 & 18.64 & 6.54 \\
\hline & & Girls & 102 & 18.26 & 6.57 \\
\hline \multirow{2}{*}{2} & \multirow{2}{*}{ Location of the School } & Rural & 86 & 17.97 & 6.05 \\
\hline & & Urban & 114 & 18.80 & 6.90 \\
\hline \multirow{2}{*}{3} & \multirow{2}{*}{$\begin{array}{ll}\text { Type of } & \text { School } \\
\text { Management } & \\
\end{array}$} & Aided & 107 & 19.68 & 7.68 \\
\hline & & Government & 93 & 17.03 & 4.57 \\
\hline \multirow{2}{*}{4} & \multirow{2}{*}{ Type of the Family } & Joint family & 60 & 17.63 & 6.09 \\
\hline & & Nuclear family & 140 & 18.80 & 6.72 \\
\hline \multirow{3}{*}{5} & \multirow{3}{*}{ Religion } & Hindu & 187 & 18.49 & 6.50 \\
\hline & & Christian & 5 & 22.80 & 7.52 \\
\hline & & Muslim & 8 & 14.75 & 5.70 \\
\hline \multirow{4}{*}{6} & \multirow{4}{*}{ Community } & OC & 18 & 20.05 & 7.40 \\
\hline & & $\mathrm{BC}$ & 86 & 17.60 & 6.26 \\
\hline & & MBC & 49 & 19.66 & 6.65 \\
\hline & & SC/ST & 47 & 18.63 & 6.60 \\
\hline \multicolumn{3}{|c|}{ Total Sample } & 200 & 18.45 & 6.54 \\
\hline
\end{tabular}

It could be seen from the table 4.3 the mean scores of the total sample is found to be 18.45. It reveals that the XI standard student's level of career competency is very low. Hence the null hypothesis 2 is accepted. Further the means scores indicate that irrespective of the XI standard student Gender, location of the school, type of school management, type of family, religion and Community, the level $\mathrm{f}$ career maturity is very low.

\section{DIFFERENTIAL ANALYSIS}

Table 3, ' $t$ ' test for Career Maturity of XI Standard Students - Gender, Location of the School, Type of School Management and Type of Family

\begin{tabular}{|c|c|c|c|c|c|c|}
\hline $\begin{array}{l}\text { Demographic } \\
\text { variable }\end{array}$ & Category & $\mathbf{N}$ & Mean & SD & $\begin{array}{l}\text { 't' } \\
\text { Value }\end{array}$ & $\begin{array}{l}\text { Level of } \\
\text { Significance }\end{array}$ \\
\hline \multirow[t]{2}{*}{ Gender } & Boys & 98 & 23.38 & 5.11 & \multirow{2}{*}{1.82} & \multirow{2}{*}{$\begin{array}{l}\text { Not } \\
\text { Significant }\end{array}$} \\
\hline & Girls & 102 & 24.80 & 5.80 & & \\
\hline \multirow[t]{2}{*}{ Locality } & Rural & 86 & 5.29 & 5.29 & \multirow{2}{*}{0.01} & \multirow{2}{*}{$\begin{array}{l}\text { Not } \\
\text { Significant }\end{array}$} \\
\hline & Urban & 114 & 24.10 & 5.69 & & \\
\hline \multirow[t]{2}{*}{ Type of school } & Aided & 107 & 24.44 & 5.42 & \multirow{2}{*}{0.93} & \multirow{2}{*}{$\begin{array}{l}\text { Not } \\
\text { Significant }\end{array}$} \\
\hline & Government & 93 & 23.72 & 5.60 & & \\
\hline \multirow[t]{2}{*}{ Type of family } & Joint family & 60 & 24.05 & 6.94 & \multirow[b]{2}{*}{0.10} & \multirow{2}{*}{$\begin{array}{l}\text { Not } \\
\text { Significant }\end{array}$} \\
\hline & Nuclear family & 140 & 24.13 & 4.79 & & \\
\hline
\end{tabular}


It could be observed from the table the calculated ' $t$ ' value $1.82,0.01,0.93$, and 0.10 are respectively not significant even at 0.05 level. It reveals that the XI standard boys and girls, rural and urban, aided and government, and joint and nuclear family do not differ significantly in their level of career maturity. Hence, the null hypothesis 2 is accepted.

Table 4, ANOVA the Career Maturity of XI Standard Students - Religion and Community

\begin{tabular}{|c|c|c|c|c|c|c|}
\hline Group & Source of Variation & SS & df & $\begin{array}{l}\text { Mean } \\
\text { square }\end{array}$ & $\begin{array}{l}\text { 'F' } \\
\text { Value }\end{array}$ & $\begin{array}{l}\text { Level of } \\
\text { Significance }\end{array}$ \\
\hline \multirow{3}{*}{ Religion } & Between groups & 56.21 & 2 & 28.10 & \multirow{3}{*}{0.92} & \multirow{3}{*}{$\begin{array}{l}\text { Not } \\
\text { significant }\end{array}$} \\
\hline & With in groups & 5987.37 & 197 & 30.39 & & \\
\hline & Total & 6043.58 & 199 & & & \\
\hline \multirow{3}{*}{ Community } & Between groups & 19.62 & 3 & 6.54 & \multirow{3}{*}{0.88} & \multirow{3}{*}{$\begin{array}{l}\text { Not } \\
\text { significant }\end{array}$} \\
\hline & With in groups & 6023.95 & 196 & 30.73 & & \\
\hline & Total & 6043.58 & 199 & & & \\
\hline
\end{tabular}

It could be seen from the table the computed ' $\mathrm{F}$ ' value $\mathbf{0 . 9 2}$ is not significant. It reveals that the there is no significant difference among the XI standard Hindu, Christian and Muslim students level of career maturity. Hence, the null hypothesis 2 is accepted.

It could be seen from the table the computed ' $F$ ' value 0.88 . It denotes that the there is no significant difference among the XI standard OC, BC, MBC and SC/ST students level of career maturity. Hence, the null hypothesis 8 is accepted.

Table 6, 't' test for Career Competency of XI Standard Students - Gender, Location of the School, Type of School Management, Type of Family

\begin{tabular}{|c|c|c|c|c|c|c|}
\hline $\begin{array}{l}\text { Demographic } \\
\text { variable }\end{array}$ & Category & $\mathbf{N}$ & Mean & SD & $\begin{array}{l}\text { 't' } \\
\text { Value }\end{array}$ & $\begin{array}{l}\text { Level of } \\
\text { Significance }\end{array}$ \\
\hline \multirow{2}{*}{ Gender } & Boys & 98 & 18.64 & 6.54 & \multirow[b]{2}{*}{0.40} & \multirow{2}{*}{$\begin{array}{l}\text { Not } \\
\text { Significant }\end{array}$} \\
\hline & Girls & 102 & 18.26 & 6.57 & & \\
\hline \multirow{2}{*}{ locality } & Rural & 86 & 17.97 & 6.05 & \multirow[b]{2}{*}{0.90} & \multirow{2}{*}{$\begin{array}{l}\text { Not } \\
\text { Significant }\end{array}$} \\
\hline & Urban & 114 & 18.80 & 6.90 & & \\
\hline \multirow{2}{*}{ Type of school } & Aided & 107 & 19.68 & 7.68 & \multirow[b]{2}{*}{2.90} & \multirow[b]{2}{*}{0.01} \\
\hline & Government & 93 & 17.03 & 4.57 & & \\
\hline \multirow{2}{*}{ Type of family } & Joint family & 60 & 17.63 & 6.09 & \multirow[b]{2}{*}{1.15} & \multirow{2}{*}{$\begin{array}{l}\text { Not } \\
\text { Significant }\end{array}$} \\
\hline & Nuclear family & 140 & 18.80 & 6.72 & & \\
\hline
\end{tabular}

It could be observed from the table the calculated t value $\mathbf{0 . 4 0 , 0 . 9 0}$ and $\mathbf{1 . 1 5}$ are respectively not significant even at 0.05 level. It reveals that the XI standard boys and girls, rural and urban, and joint and nuclear family respectively do not differ significantly in their level of career competency. Hence, the null hypothesis 9 is accepted. 


\section{A Study on Career Maturity of XI Standard Students}

It could be observed from the table the computed ' $\mathrm{t}$ ' value $\mathbf{2 . 9 0}$ is significant at 0.01 level. It suggests that the XI standard students studying in aided and government schools differ significantly in their level of career competency. Hence, the null hypothesis 11 is rejected.

Table 4.13, ANOVA the Career Competency of XI Standard Students - Religion and Community

\begin{tabular}{|c|c|c|c|c|c|c|}
\hline & $\begin{array}{l}\text { Source of } \\
\text { Variation }\end{array}$ & SS & df & $\begin{array}{l}\text { Mean } \\
\text { square }\end{array}$ & $\begin{array}{l}\text { 'F' } \\
\text { Value }\end{array}$ & $\begin{array}{l}\text { Level of } \\
\text { Significance }\end{array}$ \\
\hline \multirow{3}{*}{ Religion } & Between groups & 204.46 & 2 & 102.23 & \multirow{3}{*}{2.41} & \multirow{3}{*}{$\begin{array}{l}\text { Not } \\
\text { significant }\end{array}$} \\
\hline & With in groups & 8329.03 & 197 & 42.27 & & \\
\hline & Total & 8533.50 & 199 & & & \\
\hline \multirow{3}{*}{ Community } & Between groups & 134.45 & 3 & 44.81 & \multirow{3}{*}{1.04} & \multirow{3}{*}{$\begin{array}{l}\text { Not } \\
\text { significant }\end{array}$} \\
\hline & With in groups & 8399.04 & 196 & 42.85 & & \\
\hline & Total & 8533.50 & 199 & & & \\
\hline
\end{tabular}

It could be seen from the table the computed ' $F$ ' value $\mathbf{2 . 4 1}$ is not significant. It indicates that the there is no significant difference among the XI standard Hindu, Christian and Muslim students level of career competency. Hence, the null hypothesis 13 is accepted.

It could be seen from the table the computed ' $F$ ' value 1.04. It denotes that the there is no significant difference among the XI standard OC, BC, MBC and SC/ST students level of career competency. Hence, the null hypothesis 14 is accepted.

\section{CORRELATION ANALYSIS}

Table 4, Relationship between XI Standard Students Career Maturity and Career Competency

\begin{tabular}{|l|l|}
\hline Variables & ' $\Upsilon$ ' Value \\
\hline Career Maturity & \multirow{2}{*}{$0.15^{*}$} \\
\hline Career Competency & \\
\hline
\end{tabular}

* Significant at 0.05 level

The calculated ' $\Upsilon$ ' value 0.15 is significant at 0.05 level. It reveals that there is low relationship exists between the XI standard students level of career maturity and career competency. Hence, the null hypothesis 15 is rejected.

\section{MAJOR FINDINGS OF THE STUDY}

- The XI standard student's level of career maturity is below average.

- The XI standard student's level of career competency is very low.

- The XI standard boys and girls do not significantly differ in their level of career maturity and career competency.

- The rural and urban school XI standard students do not significantly differ in their level of career maturity and career competency. 
- The aided and government school XI standard students do not significantly differ in their level of career maturity but significantly differ in their level of career competency.

- The nuclear and joint family students do not significantly in their level of career maturity and career competency.

- There is no significant difference among the Hindu, Christian and Muslim students level of career maturity and career competency.

- There is no significant difference among the OC, BC, MBC and SC/ST student's level of career maturity and career competency.

- There is a low relationship exists between the XI standard students career maturity and career competency.

\section{RECOMMENDATIONS OF THE STUDY}

The XI standard students are adolescents. Adolescence is a period between childhood and manhood and womanhood. This growth period is important stage in the life of the students character begins to take a definite shape during adolescence.

In the present study, irrespective of sex, location of the school, type of school management, type of family, religion and community of the XI standard student's career maturity and career competency is low.

Hence, the government, teachers and parents try to provide constructive information about different careers available to the students. The school should set up the career guidance centers in the schools. The mass media try to publish the various types of career available to the students. The student's admission at the higher secondary level should be based on the student's interests, attitude and aptitude.

\section{SUGGESTIONS FOR FURTHER RESEARCH}

- An investigation into the career maturity of college students may be conducted.

- A comparative assessment of career maturity and family environment of students of different educational levels and psychological stages may be carried out.

- A similar study may be conducted in other districts, and other states.

\section{REFERENCES}

Anthony V Naidoo (1998). Demographics, Causality, work salience, and the career maturity of African-American students: A Causal model. Journal of vocational behavior, vol. 53, issue 1, August 1998, pp.15-27.

Bert W. Westbrook and D. Carol Wynne, (1994). The relationship between the career maturity inventory and appropriateness of career choices of Black Adolescents. Educational and Psychological Measurement, Sep. 1994: 54; 788-792. 
Bert W. Westhrook, et. al. (1994). Career maturity in adolescence reliability and validity of selfratings of abilities by gender and ethnicity. Journal of career assessment, Mar 1994; 2, 125-161.

Bert W. Westhrook, Terry Elrod, and Carol Wynne (1996). Career assessment and the cognitive vocational maturity test. Journal of Career Assessment, Mar 1996: 4: 139-170.

Creed (2003) Predicting two components of career maturity in school based adolescents. Journal of career development, vol.29, November 4, 2003, pp.277-290(14).

John O. Crites and Mark L., Savickas (1996). Revision of the career maturity inventory journal of career assessment. Mar 1996; 4, 131-138.

Louis A. Busacca and Brain J. Taber (2002). The career maturity inventory-revised; A preliminary psychometric investigation journal of career assessment, Nov. 2002, 10: 441455.

Mark L. Savickas (2002). The relation of career maturity to personality type and social adjustment. Journal of career assessment, vol.10, No.1, 24-49.

Mathur Gul (2001). “Career maturity among adolescents”. Psycholinguistic association of India, Raipur, INDE (1971) (Revue) vol.31, no.2, pp.85-88.

Naidoo, A.V. (1988). “Career Maturity: A review of four decades of research, Bellville, South Africa: University of the Western Cape.

Robert T. Carter and Madonna G. Constantine (2000). Career Maturity, Life role salience, and racial / ethnic identity in black and Asian American college students journal of career assessment, Apr. 2000, 8, 173-187.

Sabir A. Alvi and Sar B. Khan, (1982). A study of the criterion-related validity of crites career maturity inventory. Educational and Psychological Measurement, Dec 1982; 42, 12851288.

Shawn Anderson and Chris Brown (1997). Self-Efficacy as a Determinant of Career maturity in Urban and Rural high school seniors journal of career assessment, Jun 1997; 5, 305-315.

Wendy Patton, Peter A. Creed, and Juanita Muller (2002). Career maturity and well being as determinants of occupational status of recent school leavers: A Brief report of an Australian Study Journal of Adolescent Research, Jul 2002; 17, 425-435. 